\title{
A microarray analysis for genes regulated by interferon- $\tau$ in ovine luminal epithelial cells
}

\author{
Yizhen Chen ${ }^{1}$, Eric Antoniou ${ }^{1}$, Zhilin Liu ${ }^{1}$, Leonard B Hearne ${ }^{2}$ and R Michael Roberts ${ }^{1,3}$ \\ ${ }^{1}$ Division of Animal Sciences, University of Missouri-Columbia, Missouri 65211, USA, ${ }^{2}$ Department of Statistics, \\ University of Missouri-Columbia, Missouri 65211, USA and ${ }^{3}$ Department of Biochemistry, University of \\ Missouri-Columbia, Missouri 65211, USA
}

Correspondence should be addressed to R M Roberts, 240b CS Bond Life Sciences Center, University of Missouri-Columbia, 1201 Rollins Street, Columbia, Missouri 65211, USA; Email: robertsrm@missouri.edu

\begin{abstract}
Interferon- $\tau$ (IFNT) is released by preimplantation conceptuses of ruminant species and prepares the mother for pregnancy. Although one important function is to protect the corpus luteum from the luteolytic activity of prostaglandin-F $2 \alpha$, IFNT most likely regulates a range of other physiological processes in endometrium. Here, an immortalized cell line from ovine uterine luminal epithelial cells was treated with IFNT for either 8 or $24 \mathrm{~h}$. RNA was subjected to cDNA microarray analysis, with RNA from untreated cells as the reference standard. Of 15634 genes, $1274(8 \%)$ were IFNT responsive at $P<0.01$ and 585 at $P<0.001$ to at least one treatment. Of the latter, 356 were up-regulated and 229 down-regulated. Increasing IFNT concentrations from $10 \mathrm{ng} / \mathrm{ml}$ to $10 \mu \mathrm{g} / \mathrm{ml}$ had minor effects, and most genes up- or down-regulated at $8 \mathrm{~h}$ were regulated similarly at $24 \mathrm{~h}$. Although IFNT influences many genes implicated in antiviral activity and apoptosis, its action also likely regulates prostaglandin metabolism, growth factors and their receptors, apoptosis and the nuclear factor (NF)- $\kappa$ B cascade, extracellular matrix accretion, angiogenesis, blood coagulation, and inflammation. In particular, it increased mRNA concentrations of genes related to the vascular endothelial growth factor $\mathbf{R} 2$ pathway of angiogenesis and down-regulated ones associated with hypoxia. Two genes implicated in the antiluteolytic actions of IFNT (encoding cyclooxygenase-2 and the oxytocin receptor respectively) were downregulated in response to all treatments. IFNT targets a complex range of physiological processes during the establishment of pregnancy.

Reproduction (2007) 134 123-135
\end{abstract}

\section{Introduction}

Interferon- $\tau$ (IFNT) is generally regarded as the primary signal for maternal recognition of pregnancy in the true ruminant species such as cattle and sheep and helps to maintain the structural and functional integrity of the corpus luteum $(\mathrm{CL})$ at a time in a nonpregnant animal that this structure would be poised to regress (Roberts et al. 1992). By such intervention, IFNT allows progesterone production by the $\mathrm{CL}$ to continue and hence maintains the endometrium in a receptive state. The elongating conceptus secretes IFNT in large amounts during this period, which immediately precedes definitive attachment of trophectoderm to the uterine epithelium, i.e. 12-21 days in sheep (Hansen et al. 1988, Farin et al. 1990) and 14-25 days in cattle (Helmer et al. 1987, Farin et al. 1990). In its luteoprotective role, IFNT prevents or diminishes oxytocin-induced 'pulses' of prostaglandin F2 $\alpha$ (PGF2 $\alpha$; PGF) from the uterus, most likely by suppressing the expression of oxytocin receptors (OTR) on the luminal and upper glandular epithelial cells lining the uterus (Spencer et al. 1995a). Hence, the immediate target for IFNT action is on these epithelial cells, which are exposed to very high concentrations of this protein for an extended period of time.

IFNT is a member of the Type I IFN family (Roberts et al. 1997). These cytokines have broad pleiotropic actions on their target cells (Stark et al. 1998). Type I IFNs bind to a common receptor complex consisting of two subunit polypeptides (IFNAR1 and IFNAR2; Pestka et al. 2004), both of which are highly concentrated in uterine epithelial cells relative to other cells in ovine endometrium (Rosenfeld et al. 2002). Upon binding to the receptor, Type I IFNs activate the well-studied JAK-STAT signaling pathway (Stark et al. 1998), leading to the induction of several downstream effector genes, often named interferon-stimulated genes or ISGs. In addition, Type I IFNs activate additional signal transduction 
pathways, including components of the MAPK pathway (Uddin et al. 2000).

Several ISGs are regulated by IFNT in the endometrium of cattle and sheep (Austin et al. 1996, Chen et al. 2006, Gray et al. 2006). In sheep, at least, increased expression of some of these genes has been noted in stromal and immune cells resident in the uterus as well as in the surface and glandular epithelium (Johnson et al. 1999a, 2000, 2001a, 2002, Choi et al. 2001). In addition, different ISGs show complex and distinct patterns of expression within the endometrium, suggesting that regulation of gene expression is complex. Most of the endometrial ISGs so far studied are ones anticipated to be up-regulated as part of the classical antiviral response. It remains unclear whether the activation of these viral-response genes has any role in preparing the uterus for pregnancy. However, at least three genes, specifically those encoding estrogen receptor- $\alpha$ (ESR1; Spencer et al. 1995b, Spencer \& Bazer 1996), the OTR; Spencer et al. 1995a, Spencer \& Bazer 1996), and cyclooxygenase-2 (PTGS2; Xiao et al. 1998, 1999, Binelli et al. 2000, Pru et al. 2001) have been implicated in the antiluteolytic action of IFNT and reported to be down-regulated following IFNT exposure. Confusingly, others have been unable to confirm this result for PTGS2, which has variously been reported to be up-regulated (Asselin et al. 1997a, 1997b, Emond et al. 2004) or unaffected by IFNT (Kim et al. 2003b). We recently showed that OTR and PTGS2 gene expression were down-regulated at day 14 of pregnancy in sheep and by treatment of ewes with IFNT and concluded that the mechanism whereby IFNT acts as an antiluteolysin still remains unclear, although a strong case can be made for the involvement of OTR (Chen et al. 2006).

The endometrium responds to IFNT secreted by the conceptus in a paracrine manner. The surface epithelium of the uterine lumen is probably the primary target for IFNT, although there is also evidence that this cytokine can reach cells in the underlying stroma (Johnson et al. 1999b, 2000, 2001b, Hicks et al. 2003) and even the myometrium (Ott et al. 1998, Johnson et al. 1999d, Hicks et al. 2003), suggesting that the epithelium does not act as a completely impermeable barrier to conceptus-derived proteins. Although cell lines from a number of sources have been used to explore the biological activities of IFNT, including ones from nonendometrial tissues, such as L929 (mouse fibroblast) cells, WISH (human amnion) cells, Daudi (human B-cell) cells, human $2 \mathrm{fGH}$ (human fibrosarcoma) cells, and U3A (STAT1-deficient 2fTGH) cells (Alexenko et al. 1997, 1999, Stewart et al. 2001b, Kim et al. 2003a), cells or tissue explants from endometrium clearly provide the best models for studying the physiological role of IFNT. In this paper, we have chosen to examine the effects on an immortalized luminal epithelial (LE) cell line initially isolated at day 5 of the estrous cycle (Johnson et al. 1999C). The LE line has been relatively well characterized and mimics at least some of the responses of the ovine uterus to IFNT in terms of ISG expression (Johnson et al. 1999c, Stewart et al. 2001a). These cells express estrogen and progesterone receptors (Johnson et al. 1999c) and both Type I IFN receptor subunits, IFNAR1 and IFNAR2 (Rosenfeld et al. 2002). They provide a convenient means for studying the effects of IFNT on gene expression in a specific ovine uterine cell type, although it would be naïve to assume that these cells can exactly recapitulate responses in vivo. Nevertheless, data from such cells can provide insight into the range of IFNT-regulated genes and pathways likely to be modulated by IFNT during pregnancy, and can be compared with existing in vivo information on gene expression changes that occur in response to the presence of a conceptus (Ishiwata et al. 2003, Bauersachs et al. 2006, Klein et al.2006) or to exposure of the uterine tract to IFNT (Chen et al. 2006, Gray et al. 2006).

We have examined two kinds of response of the LE cells to IFNT, namely the effects of concentration and time of exposure, since both variables have been reported to be important. For example, IFNT increased PGE2 production in a dose-dependent manner (Asselin et al. 1997b, 1997c), and while low concentrations (equivalent to $5 \times 10^{-8} \mathrm{M}$ or less) inhibited the production of PGF in primary bovine endometrial cell cultures (Xiao et al. 1998, 1999, Asselin \& Fortier 2000), high concentrations $\left(\sim 5 \times 10^{-7} \mathrm{M}\right)$ promoted such production (Asselin et al. 1997a, 1997c, Parent et al. 2003). In addition, IFNT reduced PTGS2 mRNA at 6 h or earlier but not at later time points (Xiao et al. 1999). To limit the number of analyses, we chose two exposure times: 8 and $24 \mathrm{~h}$. The former was anticipated to provide data on 'early' and 'intermediate' genes, the second on genes whose regulation was late and possibly secondary to the initial response to IFNT.

Although gene transcript profiling for IFN-responsive genes in human cells was first performed in 1998 (Der et al. 1998), there have been few other comprehensive studies since then in any species. Genes that respond to ovine IFNT have been described in human fibroblast cells (Stewart et al. 2001 b, Kim et al. 2003a). In addition, our laboratory has examined the expression of 70 genes considered likely to be IFNT responsive in endometrium of ewes that were either pregnant or had been administered IFNT (Chen et al. 2006), while, in the same species, Gray et al. (2006) used a microarray representing $\sim 5000$ ovine genes to study genes regulated during pregnancy and in response to a combination of IFNT and progesterone. In the present study, we have made the use of a 15634 bovine unigene set to analyze IFNT responses in LE cells. There were four goals. The first was to determine whether the changes we observed earlier (Chen et al. 2006) in endometrium of ewes, including effects on genes influencing prostaglandin metabolism, would be reproduced in the epithelial cell line. The second and third goals were to determine whether raising the concentration and time of exposure 
to IFNT would influence gene expression profiles, recalling that the surface epithelium of the intact uterus must be exposed to unusually high amounts of the cytokine for several days. The final goal was to generate a comprehensive list of genes regulated by IFNT in ovine endometrium. Presumably, the responses of some but not necessarily all of these genes provide the basis for how IFNT mediates changes in the mother that provide for a successful establishment of pregnancy.

\section{Materials and Methods}

\section{Cell culture}

The LE cells were maintained in Dulbecco's modified Eagle's medium with F12 salts (DMEM/F12; Sigma-Aldrich Corp.), pH 7.4, containing 10\% (v:v) fetal bovine serum (Gibco-BRL) and penicillin/streptomycin/amphotericin B solution (100 IU/ml, $0.1 \mathrm{mg} / \mathrm{ml}, 0.25 \mu \mathrm{g} / \mathrm{ml}$; Gibco-BRL) as described previously (Johnson et al. 1999c).

\section{Recombinant ovIFNT}

Recombinant protein was produced as described elsewhere (Ealy et al. 1998a, 1998b). Antiviral assays to assess potency of the preparation were performed on MDBK cell (ATCC\#CCL22, American Type Culture Collection; Ealy et al. 1998b). The antiviral activity of this preparation of IFNT was $2 \times 10^{8}$ international units/mg.

\section{Treatment of cells with IFNT}

For the microarray experiments, three stocks of LE cells, frozen on different occasions, were used. Each experiment, which was performed thrice, employed three replicate groups of cells representing the three different cell stocks. Both experiments had an identical experimental design. In each, cells were allowed to reach $\sim 80 \%$ confluence in $75 \mathrm{~cm}$ tissue culture flasks. The medium was then replaced with $5.0 \mathrm{ml}$ fresh DMEM/F12 containing either recombinant ovine IFNT at two different concentrations $\left(10 \mathrm{ng} / \mathrm{ml} ; \sim 5 \times 10^{-10} \mathrm{M}\right.$ and $10 \mu \mathrm{g} / \mathrm{ml}$; $\left.\sim 5 \times 10^{-7} \mathrm{M}\right)$ or with the IFNT vehicle $(1 \times \mathrm{PBS})$ as a control (Parent et al. 2003). The lowest concentration of
IFNT was close to the $K_{\mathrm{D}}$ for the ovine receptor, while the highest was supersaturating, but probably closer to IFNT concentrations in the uterine lumen at the time of maximal production by the conceptus. Cells were exposed to IFNT for either 8 or $24 \mathrm{~h}$ before isolation of RNA. There were, therefore, 36 samples (9 per treatment) of RNA prepared (see below). Cultures of pooled, untreated (control) cells that were harvested at the 8 -h time point provided the reference RNA for both the microarray and real-time PCR analyses (Table 1).

\section{Microarray analysis}

The DNA array slides were made by spotting cDNA PCR products in $3 \times$ SSC solutions onto the poly-L-lysine coated glass slides. Each array contained 17692 cDNA probes from an available cDNA library of 16156 probes (Smith et al. 2001) and a bovine ovary EST library with 1536 probes (Takasuga et al. 2001). In addition, the new library represented 15634 unique sequences.

RNA was isolated from individual plates of cells using RNA STAT-60 (Tel-Test, Friendswood, TX, USA) according to manufacturer's recommendations. The quantity of RNA for each extraction was determined by measuring absorbance at $260 \mathrm{~nm}$; purity was calculated from the ratios of absorbance at 260 and $280 \mathrm{~nm}$; and quality was evaluated by agarose gel electrophoresis. Extracted RNA was stored at $-80^{\circ} \mathrm{C}$. For the microarray analysis, the triplicate samples for each of the four experimental treatments were pooled (RNA ratio 1:1:1) to provide four pools of RNA. Since the experiment was performed thrice, there were 12 RNA sample pools in total, which were each analyzed through a comparison with a single sample of control RNA from untreated cells. Thus, each RNA sample represents pooled material from three different isolates of LE cells, thereby minimizing any confounding effect of variation among different batches of cells.

The microarray analysis utilized also-called Reference Design approach in which we compared RNA from the various treatment groups with the control RNA, following the microarray protocol from TIGR (The Institute for Genomic Research; Hegde et al. 2000). RNA (15 $\mu \mathrm{g})$ was reverse transcribed using

Table 1 Real-time PCR analysis of mRNA expression in ovine luminal epithelial cells treated with interferon- $\tau$ (IFNT).

\begin{tabular}{|c|c|c|c|c|c|}
\hline \multirow[b]{2}{*}{ Gene } & \multirow[b]{2}{*}{ None } & \multicolumn{2}{|c|}{ IFNT $(0.001 \mathrm{mg} / \mathrm{ml})$} & \multicolumn{2}{|c|}{ IFNT (10 mg/ml) } \\
\hline & & $8 \mathrm{~h}$ & $24 \mathrm{~h}$ & $8 \mathrm{~h}$ & $24 \mathrm{~h}$ \\
\hline ISG15 & $1.0 \pm 0.5$ & $8.7 \pm 0.9 *(23.9)$ & $6.1 \pm 0.8^{*}(30.7)$ & $6.6 \pm 0.8^{*}(13.8)$ & $7.3 \pm 0.9 *(30.7)$ \\
\hline OTR & $1.0 \pm 0.2$ & $0.30 \pm 0.1 *(0.40)$ & $0.34 \pm 0.1 *(0.77)$ & $0.45 \pm 0.1 *(0.73)$ & $0.39 \pm 0.1 *(0.51)$ \\
\hline IGF2 & $1.2 \pm 0.4$ & $0.43 \pm 0.1 *(0.88)$ & $0.31 \pm 0.2 *(0.69)$ & $0.28 \pm 0.1 *(0.81)$ & $0.35 \pm 0.1 *(0.79)$ \\
\hline PTGS2 & $1.0 \pm 0.1$ & $0.32 \pm 0.1 *(0.65)$ & $0.36 \pm 0.1 *(0.77)$ & $0.40 \pm 0.1 *(0.61)$ & $0.42 \pm 0.2 *(0.76)$ \\
\hline HIF1A & $1.1 \pm 0.4$ & $0.26 \pm 0.1 *(0.80)$ & $0.22 \pm 0.08 *(0.77)$ & $0.37 \pm 0.1 *(0.79)$ & $0.29 \pm 0.2 *(0.83)$ \\
\hline
\end{tabular}

*Effect of treatment $(P<0.01)$. Real-time PCR was used to measure the fold decrease or increase in target gene mRNA in IFNT-treated cells. The values presented are from independent experiments, each conducted in triplicate. Values in parentheses were the changes in expression as assessed on the microarrays. OTR was not represented on the microarray. 
SuperScript III reverse transcriptase (Invitrogen) to provide incorporation of the reactive amine derivative of dUTP, 5-(3-aminoallyl)-2'-deoxyuridine 5'-triphosphate (Sigma) into the cDNA. After removing free nucleotides, the aminoallyl-labeled samples were coupled to dye. The cDNAs from treated and control were labeled separately with either cyanine 3 (Cy3) or Cy5 dyes by standard procedures (Amersham Biosciences). The resulting labeled probes were purified, mixed together, and then redissolved in $25 \mu$ hybridization solution $(50 \%$ formamide, $5 \times \mathrm{SSC}, 0.1 \% \mathrm{SDS}$, $10 \mu \mathrm{g}$ ovine Cot- $1 \mathrm{DNA}$, and $10 \mu \mathrm{g}$ poly-A in water). The samples were denatured and then applied to the microarrays. After incubation at $42{ }^{\circ} \mathrm{C}$ for $16 \mathrm{~h}$, the arrays were sequentially washed with $1 \times \mathrm{SSC} / 0.2 \%$ SDS, $0.1 \times$ SSC $/ 0.2 \%$ SDS, and $0.1 \times$ SSC solutions. The arrays were then dried and scanned using a Genepix 4000B scanner (Axon Instruments, Union City, CA, USA) and analyzed by the Genepix Pro software. As a control, the dye labeling was reversed in one of the hybridizations (dye-swap control).

\section{Data analysis}

The intensity value of each spot for Cy3 and Cy5 fluorescence (media foreground intensity minus media background intensity) was analyzed by R/MAANOVA (MicroArray ANOVA; Wu et al. 2002), which runs in the statistical software program ' $R$ ' (Beckers et al. 1988) from www.r-project.org. Briefly, data were first normalized by means of the regional Lowess algorithm to account for systematic intensity dependence and spatial variation in microarray log ratios, which is to correct the bias caused largely by differences of dye incorporation (Berger et al. 2004). Then, a two-stage ANOVA model was applied to the data. In the first stage, the model was

$Y_{i j k g r}=\mu+A_{i}+D_{j}+A D_{i j}+r_{i j k g r}$

where $Y$ is the log intensity reading for a particular gene on a certain array, e.g. array $i$, dye $j$ of RNA variety $k ; \mu$ is the overall mean; $A_{i}$ is the effect of array $i(i=1, \ldots, 12), D_{j}$ is the effect of dye $j(j=1,2)$; and $A D$ is the effect of array and dye interactions. This is the cross-gene stage of the calculation, which removes the overall effects of array, dye effects, and the effects of array and dye interactions.

The residual of the first stage is used as the input for the second stage, which is the gene-specific model.

$r_{i j k g r}=G+A G_{i}+D G_{j}+V G_{k}+\varepsilon_{i j k r}$

Here, $G$ is the average effect of the gene, $A G$ is the arrayby-gene variation, and $D G$ is the dye-by-gene variation. $V G$ is the effects of the treatment on the expression of the gene of interest. The error $\varepsilon$ is the residual. A permutation F-test (Cui \& Churchill 2003) was applied by MAANOVA, and the adjusted $P$ values were calculated for every gene to indicate if expression was changed by treatment. Finally, a two-dimensional hierarchical clustering analysis was performed using GeneCluster (www. broad.mit.edu/cancer/software/genecluster2/gc2.html) and TreeView software (Eisen et al. 1998; http://rana.lbl. gov/EisenSoftware.htm; Fig. 1). We combined use of the DAVID Bioinformatics Resources Data Base (2006; http://david.abcc.ncifcrf.gov/; Dennis et al. 2003, Brunner et al. 2004) with manual examination of regulated genes to provide functional annotation clustering.

\section{Real-time PCR analysis}

The relative expression levels of five selected ovine genes were determined by real-time PCR in part to confirm the reproducibility of the microarray and also to provide additional quantitative data for genes of particular interest. Primers specific for the genes for ISG-15/17, originally known as ubiquitin cross-reactive protein (ISG15), PTGS2, OTR, insulin-like growth factor-2 (IGF2), and hypoxiainducible factor 1 subunit $\alpha$ (HIF1A) were designed with Primer Express software (Applied Biosystems, Foster City, CA, USA). The primer pairs are listed in Supplementary Table 1 which can be viewed online at www.reproductiononline.org/supplemental/.

Real-time PCR was performed and analyzed by using an $\mathrm{ABI}$ prism 7500 sequence detection system (Applied Biosystems). The protocol for real-time RT-PCR analysis has been described earlier (Chen et al. 2006). Relative expression in comparison with ribosomal protein L19 (RPL19) was calculated by the comparative $C_{\mathrm{T}}$ method (threshold cycle). The relative quantitation of candidate gene expression in each treatment groups was determined by using the comparative $C_{\mathrm{T}}$ method $\left(2^{-\Delta \Delta C_{\mathrm{T}}}\right)$ as described in user bulletin $2 \mathrm{ABI}$ Prism 7500 Sequence Detection System.

Each of the five transcripts was amplified in triplicate in a single PCR run. The entire experiment was then repeated with RNA from two additional experiments from the same treatment to provide a total of three replicates. Real-time PCR quantification of gene expression level in each treatment was the mean of three real-time RT-PCR experiments. Differences in relative $\mathrm{mRNA}$ expression between experimental groups were assessed by one-way ANOVA, followed by pairwise comparison and by using a least significant difference test (Brunner et al. 2004). All experimental data are shown as the mean \pm s.E.M. Values were considered significantly different at $P<0.05$.

\section{Results}

\section{Identification of IFN- $\tau$ responsive genes}

Using the linear mixed model described in the Material and Methods, we identified 585 genes that had altered expression level at an adjusted $P$ value $<0.001$ following IFNT treatments (Supplementary Table 2 which can 


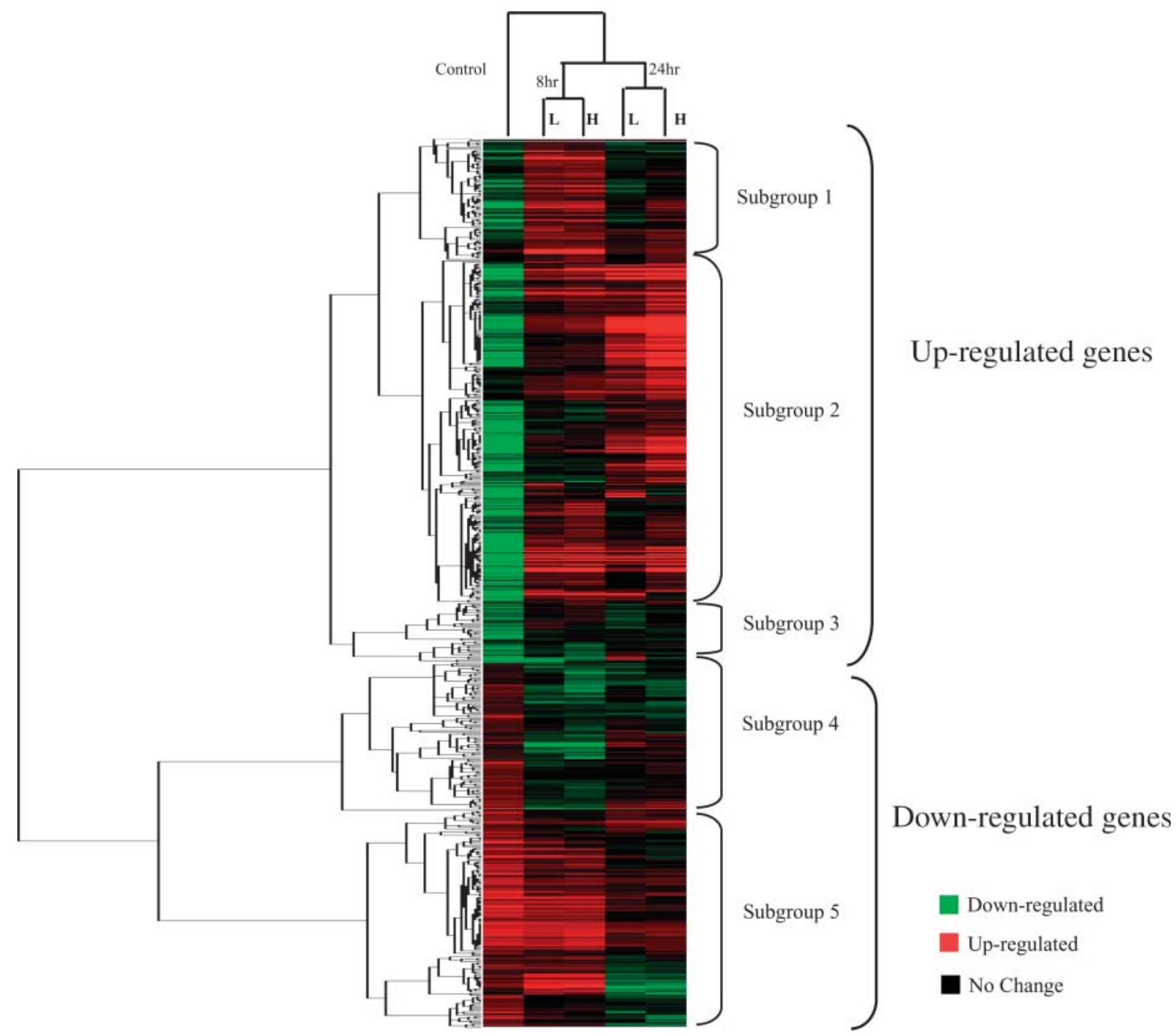

Figure 1 Two-way hierarchical cluster analysis of gene expression in control- and IFNT-treated LE cells. Here we show only the 585 genes that are differentially regulated $(P<0.001)$. The gene set depicts two major groups (up- or down-regulated), which can be further divided into five subgroups (subgroups 1-5). The data clustered according to treatment time (8 and $24 \mathrm{~h}$ ) and dose of IFNT used (L, low; H, high).

be viewed online at www.reproduction-online.org/ supplemental/). At least another $\sim 700$ genes (a total of 1274 or $8 \%$ of all genes) were IFNT responsive if the threshold of significance was raised to an adjusted $P$ value $<0.01$ (data available upon request). Among the 585 genes in Supplementary Table 2, 567 have annotations that are based on sequence similarity with known genes. We applied a two-way (genes and treatments) hierarchical clustering method (Eisen et al. 1998) on the 585 genes regulated by IFNT relative to the expression of the same genes in untreated cells that had been isolated $8 \mathrm{~h}$ after the addition of IFNT to the treatment groups (Fig. 1). The treatments clustered into two main branches, which corresponded to the 8 and $24 \mathrm{~h}$ treatments. The genes regulated by the low $(10 \mathrm{ng} / \mathrm{ml})$ and high $(10 \mu \mathrm{g} / \mathrm{ml})$ treatment groups formed two groups within these main branches of the tree, i.e. according to the duration of the treatments. Two major groups of genes can be easily recognized, one that consists of genes that were up-regulated in one or more of the treatments and a second that consists of down-regulated genes. A few genes were up-regulated at one time point and downregulated at the other. In general, a concentration of $10 \mathrm{ng} / \mathrm{ml}$ IFNT was about as effective as $10 \mu \mathrm{g} / \mathrm{ml}$. Based on visual inspection of the expression patterns, the genes illustrated in Fig. 1 could be divided arbitrarily into five subgroups, although there were distinct expression patterns visible within each grouping.

Members of subgroup 1 (Supplementary Table 3 which can be viewed online at www.reproductiononline.org/supplemental/), which contains 68 genes, were generally expressed more strongly at $8 \mathrm{~h}$ than at $24 \mathrm{~h}$ (Fig. 1), although there were several exceptions. The genes in subgroup 1 encode products with a broad range of biochemical roles. Among them are the genes for transcription factors associated with downstream action 
of Type 1 IFN, including RNF31 (interferon-stimulated transcription factor $3-\gamma 48 \mathrm{kDa}$ ) and interferon regulatory factor 7 (IRF7), three guanylate-binding proteins (GBP4, GBP5, and GEM), and a few genes encoding inflammatory cytokines, e.g. TNFSF10 and IL6ST. The extent of up-regulation of the subgroup 1 genes by IFNT at both the low and high concentrations was relatively modest when compared with many of the genes in subgroup 2 discussed below.

Subgroup 2 comprises 252 genes (Supplementary Table 4 which can be viewed online at www. reproduction-online.org/supplemental/) whose expression was, in general, sustained over $24 \mathrm{~h}$ (Fig. 1). Subgroup 2 contained the majority of the genes that were up-regulated fivefold or more by IFNT. Many of these highly up-regulated genes have long been recognized as responsive to Type I IFN, and many are included in the original list of genes identified by microarrays in human cells (Der et al. 1998, Kim et al. 2003a). They include $M x 1$, ISG15, interferon-induced protein 6-16 (G1P3), interferon-induced protein with tetratricopeptide repeats (IFIT2), 2'-5'-oligoadenylate synthetase (OAS1), IFN-induced protein-35 (IFI35), multiple $(\mathrm{MHC}$ genes from classes I and II, and $\beta-2-$ microglobulin (PDLIM3). Many of the proteins encoded by these subgroup 2 genes contribute to the antiviral response of cells targeted by Type 1 IFN and are 'classical' ISGs (Stark et al. 1998).

Subgroup 3 consists of 31 genes that were modestly, but significantly up-regulated by IFNT at $8 \mathrm{~h}$ but provided inconsistent temporal patterns of expression thereafter. The genes did not appear to fall into any particular functional class (Supplementary Table 5 which can be viewed online at www.reproduction-online.org/ supplemental/).

Subgroup 4 is comprised 87 genes that were downregulated by all IFNT treatments (Fig. 1; Supplementary Table 6 which can be viewed online at www.reproductiononline.org/supplemental/). IFN responses were, in general, sustained over the 24-h exposure to IFNT. This cohort contains several genes of potential interest in endometrial responses to pregnancy, including ones encoding metalloproteinases, the OTR, prostaglandin synthase, and IGF-2, which are discussed later.

The final subgroup contains 123 genes that were generally more strongly down-regulated at $24 \mathrm{~h}$ than at $8 \mathrm{~h}$ (Supplementary Table 7 which can be viewed online at www.reproduction-online.org/supplemental/). Again the responses to the high IFNT concentration were only marginally different from those at the low concentration.

\section{Validation of gene expression by real-time PCR}

To validate our results from the multiple microarray analyses, we performed real-time PCR experiments on five selected genes. ISG15 was chosen as a positive control for validating the experimental procedure because it has been previously shown to be up-regulated by IFNT in ovine LE cells (Johnson et al. 1999c). We selected PTGS2, IGF2, and hypoxia-inducible factor- $1 \alpha$ subunit (HIF1A), because we had previously demonstrated these genes to be down-regulated in endometrium from ewes that were either pregnant or, alternatively, treated with IFNT (Chen et al. 2006). OTR was selected because of its importance in controlling endometrial responses to oxytocin. In general, the results from real-time PCR experiments showed the same trends as the microarray experiments (Table 2), although the magnitude of fold-changes was sometimes quite different. One possible explanation is that the real-time PCR experiments were performed on un-pooled samples of RNA obtained from individual plates of cells, while the microarrays employed pooled RNA from replicate samples within an experiment.

\section{Discussion}

These experiments, employing microarrays based on bovine EST sequences, allowed us to collect data on over 15000 genes, the majority of which were at least partially annotated by comparison with human data. Our study identified a large number of genes that have altered expression patterns when LE cells were treated with IFNT. We did not employ a cutoff based on a particular value of

Table 2 Regulated genes in prostaglandin metabolic pathway.

\begin{tabular}{|c|c|c|c|c|c|c|}
\hline Unigene cluster ID & Gene name & Gene symbol & $\begin{array}{c}\mathbf{8 ~ h} \\
(10 \mathrm{ng} / \mathrm{ml})\end{array}$ & $\begin{array}{c}\mathbf{8} \mathbf{h} \\
(10 \mu \mathrm{g} / \mathrm{ml})\end{array}$ & $\begin{array}{c}\mathbf{2 4} \mathbf{h} \\
(10 \mathrm{ng} / \mathrm{ml})\end{array}$ & $\begin{array}{c}\mathbf{2 4} \mathbf{h} \\
(10 \mu \mathrm{g} / \mathrm{ml})\end{array}$ \\
\hline Bt.23094 & $\begin{array}{l}\text { Prostaglandin-F synthase } 1 \\
\text { (PGF synthase } 1 \text { ) } \\
\text { Prostaglandin } \mathrm{G} / \mathrm{H} \text { synthase } 2 \\
\text { precursor }\end{array}$ & $A K R 1 C 1$ & 0.5 & 0.65 & 0.6 & 0.7 \\
\hline Bt.15758 & Cyclooxygenase-2 (COX-2) & PTGS2 & 0.65 & 0.77 & 0.61 & 0.76 \\
\hline Bt.8953 & Prostaglandin E synthase (PGES) & PTGES & 1.41 & 1.4 & 1.37 & 1.93 \\
\hline Bt.9662 & $\begin{array}{l}\text { Prostaglandin E receptor } 4 \text { (PGE } \\
\text { receptor, EP4) }\end{array}$ & PTGER4 & 1.84 & 1.75 & 1.85 & 1.81 \\
\hline Bt.22672 & $\begin{array}{l}\text { NAD +-dependent 15-hydoxyprosta } \\
\text { glandin dehydrogenase (PGDH) }\end{array}$ & PGDH & 2.09 & 1.47 & 1.86 & 1.45 \\
\hline Bt.2990 & Prostaglandin transporter (PGT) & $S L C 21 A 2$ & 4.33 & 1.25 & 2.51 & 1.6 \\
\hline
\end{tabular}


fold-change, e.g. twofold, since there is no reason to assume that values of less than this arbitrary value are of minor significance. Also in absence of a detailed timecourse, it is not possible to infer whether a low fold-change at $8 \mathrm{~h}$, for example, does not reflect a more major change at an earlier or later time point. We chose to concentrate on the 'top' 585 genes (of which 567 were at least partially annotated) where the changes were highly significant (adjusted $P<0.001$ ). Of these genes, 356 were up-regulated, while the reminder showed a reduction in expression. Although some of these genes were late responders, most were fully up- or down-regulated within $8 \mathrm{~h}$. In addition, the lowest concentration of IFNT, which was deliberately chosen to be close to the $K_{\mathrm{D}}$ for the ovine receptor (Knickerbocker \& Niswender 1989, Li \& Roberts 1994), was generally about as effective as the highest concentration $\left(\sim 100 \times K_{\mathrm{D}}\right)$ in causing changes in gene expression, although there were some exceptions (Supplementary Table 2). This result is consistent with the assumption that Type I IFNs are effective at low receptor occupancy (Alexenko et al. 1997).

Other experiments employing microarrays to study the effects of IFNA and IFNB on human cells also indicated that large numbers of genes are responsive to Type I IFN (Der et al. 1998). Kim et al. (2003a) identified 101 IFNTresponsive genes in human U3A (STAT1-deficient 2fTGH) cells. Most recently, Gray et al. (2006) identified 180 genes that were regulated by IFNT independently of progesterone in day 14 ovine endometrium. Yan et al. (2004) in a proteomics analysis performed on human liver cells reported that as many as 1364 polypeptides were regulated by IFNA. In addition, these data illustrate the many downstream effects of Type I IFN on their targets. As in all previous studies, the majority of the IFNresponsive genes shown in Supplementary Table 2 were difficult to categorize, possibly reflecting the broad, pleiotropic effects of Type I IFN on their target cells. Many of these same IFNT-responsive genes, particularly ones implicated in an antiviral response, have been observed to be regulated during pregnancy in cattle and sheep, although it is clear that early maternal responses to the presence of a conceptus are likely to be more than simply a result of exposure of LE cells to IFNT. However, a number of interesting patterns of gene expression change that might relate to the effects of IFNT during pregnancy could be discerned.

Although our results agree closely with an in vivo IFNT study performed on a limited number of selected genes ( 70 vs 15000 in the present study; Chen et al. 2006), they are difficult to compare with another, recent, in vivo study that utilized microarray technology (Gray et al. 2006). The latter utilized $\sim 5000$ ovine ESTs and a relatively complex experimental design, in which IFNT effects were distinguished from those of progesterone by exposing endometrium of some ewes to an antiprogestin. Gray et al. (2006) described 180 genes regulated by IFNT, but many of these were not represented in our gene list (Supplementary Table 2) and vice versa. Some of the more interesting differences are remarked upon later in the discussion that follows.

\section{IFNT regulates the prostaglandin synthesis pathway}

The production and release of uterine PGF is crucial to controlling the regression of the $\mathrm{CL}$ during early pregnancy in cattle and sheep (McCracken et al. 1999). Conversely, PGE2 is luteotrophic (Magness et al. 1981, Thibodeaux et al. 1992). As shown in Fig. 2, the production of these prostaglandins is controlled by several enzymes, including PTGS2, PGE synthase (PGES), PGF synthase (AKR1C1), and PG 15-dehydrogenase (PTGES), and their metabolism by several other gene products, including 15-hydroxy prostaglandin dehydrogenase (PGDH) and the prostaglandin transporter (SLC21A2). Of these, PTGS2, which is responsible for the conversion of arachidonic acid into $\mathrm{PGH} 2$, is considered to catalyze the rate-limiting step in the biosynthesis of prostaglandins in endometrial tissue (Simmons et al. 2004). In addition, an increase in the PGE2:PGF ratio in favor of PGE2 occurs during pregnancy in sheep and cattle (Silvia et al. 1984, Payne \& Lamming 1994). The regulation of PTGS2 expression by IFNT has been exceedingly controversial, with some reporting an increase and others a decrease in expression of either the enzyme or the mRNA (see Introduction). In the present study, it is clear that PTGS2 and PGF synthase (AKR1C1) gene expression are down-regulated in LE cells in response to IFNT, while transcripts for PGE2 synthase (PGES) increase in concentration. We obtained essentially identical results when comparing endometrium from day 14 pregnant and nonpregnant ewes and after ewes at day 14 of their estrous cycles had been treated with IFNT (Chen et al. 2006). These data contrast with other data (Gray et al. 2006) in which PTGS2 gene expression was up-regulated in response to IFNT

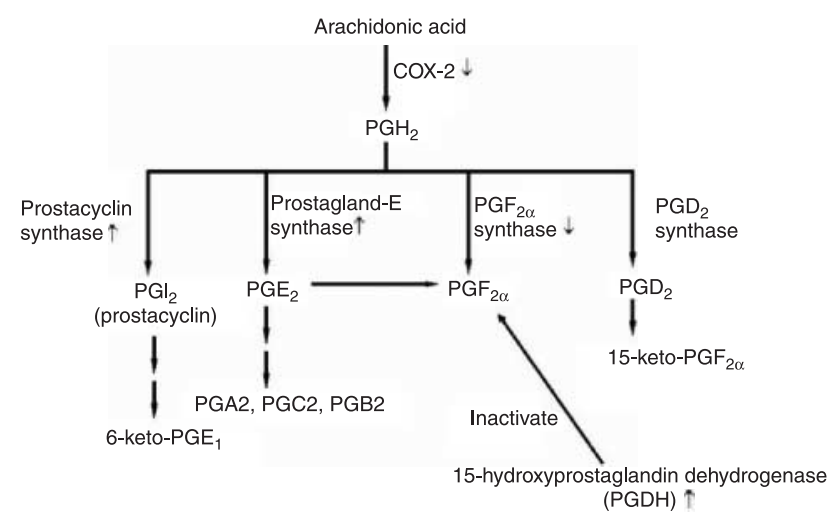

Figure 2 Prostaglandin metabolism in mammalian cells. The diagram is based on one downloaded from http://www.genome.jp/kegg/. Up or down arrows indicate whether the gene is positively or negatively regulated by IFNT in the LE cells. 
treatment. We have no explanation for these differences in outcome. Changes in expression of other genes with a role in prostaglandin metabolism and action were also evident. Transcripts for PGDH, the PGE receptor (PTGER4), and the prostaglandin transporter (SLC21A2), for example, increased. Overall, our data are generally consistent with the view that IFNT treatment favors PGE production over PGF (Fig. 2).

None of the genes in Fig. 2 thought to be involved in PGF metabolism appeared to be differentially responsive as IFNT concentrations were raised from $10 \mathrm{ng} / \mathrm{ml}$ to $10 \mu \mathrm{g} / \mathrm{ml}$. Thus, we were unable to provide any supporting evidence for the view (Asselin \& Fortier 2000) that prostaglandin metabolism, and specifically the production of PGF, might differ according to the concentrations of IFNT employed, with low concentrations favoring lowered PGF production and high concentrations favoring an increase. On the other hand, transcript profiling can be misleading since it provides only information relating to mRNA concentrations and nothing about how well these messages are translated or the concentration of relevant proteins in the cells.

\section{IFNT up-regulate components of signal transduction pathways}

Type I IFN signaling has been studied extensively. Since all Type I IFN share the same receptor complex, IFNT is likely to activate some or all of the signal pathways employed by IFNA and IFNB, including the JAK-STAT, and MAPK pathways (de Veer etal. 2001). Our data indicate that IFNT, as expected, up-regulated genes encoding key components of these two signaling pathways, STAT1 and RNF31 in the JAK-STAT pathway and MAP3K14 (Supplementary Tables 2 and 3) from the MAPK pathway. Components of the two pathways have also been identified as IFNA-responsive genes in human cell lines (Der et al. 1998, de Veer et al. 2001). At least 16 transcription factors, presumably downstream of IFNT, increased in expression, and at least three were down-regulated (Supplementary Table 8 which can be viewed online at www.reproductiononline.org/supplemental/). With the exception of STAT1, $R N F 31$, IRF7, and IRF9, however, the relationship of these transcription factors to the action of Type 1 IFNs has not been explored.

\section{IFNT promotes increased expression of inducers of apoptosis and intracellular proteolysis}

A DAVID annotation analysis indicated that 24 genes $(P<0.00006)$ in Supplementary Table 1 were associated with control of apoptosis, with the majority up-regulated. We have listed some of these genes in Table 3. They include $B A D(\mathrm{Bcl}-2$ antagonist of cell death), (Yang et al. 1995), BID (BH3-interacting domain death agonist), which induces caspases and apoptosis and counters the protective effect of $\mathrm{Bcl}-2$ (Wang et al. 1996), and BNIP3L (Bcl2/adenovirus E1B $19 \mathrm{kDa}$ protein-interacting protein 3-like), a wellcharacterized inducer of apoptosis (Opferman \& Korsmeyer 2003). The genes for caspase 8 (CASP8) and several proteosome components were also up-regulated. The ability of Type I IFNs to cause apoptosis (Chawla-Sarkar et al. 2003) and induce genes involved in apoptosis (Der et al. 1998, Leaman et al. 2003) is well established in human target cells and cultured epithelial cells from bovine endometrium (Wang et al. 2003) although we have not examined whether cell death resulted in the LE cells used here. Similarly, a link between IFN action and induction of proteosomal activity has been described by others ( $\mathrm{Li} \&$ Hassel 2001, Liu et al. 2003). These changes in gene expression may reflect a potential ability of conceptus IFNT to cause remodeling of the uterine epithelium and underlying stromal tissue prior to firm attachment of the trophoblast to the uterine wall.

Table 3 Regulated genes related to apoptosis.

\begin{tabular}{|c|c|c|c|c|c|c|}
\hline Unigene cluster ID & Gene name & Gene symbol & $\begin{array}{c}\mathbf{8} \mathbf{h} \\
(10 \mathrm{ng} / \mathrm{ml})\end{array}$ & $\begin{array}{c}\mathbf{8} \mathbf{h} \\
(10 \mu \mathrm{g} / \mathrm{ml})\end{array}$ & $\begin{array}{c}\mathbf{2 4} \mathbf{h} \\
(10 \mathrm{ng} / \mathrm{ml})\end{array}$ & $\begin{array}{c}\mathbf{2 4} \mathbf{h} \\
(10 \mu \mathrm{g} / \mathrm{ml})\end{array}$ \\
\hline Bt.42335 & Protein 2-like (BNIP2L) & LOC483190 & 1.91 & 1.87 & 1.91 & 1.83 \\
\hline Bt.888 & $\begin{array}{l}\text { BCL2/adenovirus E1B } 19 \mathrm{kDa} \text {-interacting } \\
\text { protein 3-like (BNIP3L) }\end{array}$ & $B N I P 3 L$ & 1.12 & 1.47 & 1.22 & 1.4 \\
\hline Bt.7953 & $\begin{array}{l}\text { BCL2-antagonist of cell death protein } \\
\text { (BAD) }\end{array}$ & $B A D$ & 1.62 & 1.47 & 1.6 & 1.28 \\
\hline Bt.3222 & $\begin{array}{l}\text { BH3-interacting domain death agonist } \\
\text { isoform } 1 \text { (BID isoform 1) }\end{array}$ & $B I D$ & 1.47 & 1.52 & 1.34 & 1.35 \\
\hline Bt.26611 & CASP8-associated protein 2 & CASP8AP2 & 1.29 & 1.68 & 1.32 & 1.28 \\
\hline Bt.41872 & Caspase 8 isoform B & CASP8B & 1.08 & 1.22 & 1.93 & 1.18 \\
\hline Bt.1793 & $\begin{array}{l}\text { Cell death regulator aven; programmed } \\
\text { cell death } 12\end{array}$ & AVEN & 1.6 & 1.4 & 1.4 & 1.32 \\
\hline Bt.21648 & Cell death-inducing DFFA-like effector b & CIDEB & 1.34 & 1.64 & 1.25 & 1.1 \\
\hline Bt.3682 & $\begin{array}{l}\text { Death-associated protein } 6 \text { (Fas-binding } \\
\text { protein) }\end{array}$ & $F A D D$ & 1.56 & 1.91 & 1.12 & 1.49 \\
\hline Bt.725 & $\begin{array}{l}\text { Platelet-derived growth factor receptor- } \\
\text { like (PDGFRL) }\end{array}$ & PDGFRL & 1.56 & 1.09 & 1.4 & 1.03 \\
\hline
\end{tabular}


Interestingly, at least seven genes $(P<0.005)(F A D D$, TNFSF10, SCOTIN, TRIM38, BST2, CXXC5, EEFID) associated with control of the NF- $\kappa B$ cascade were up-regulated by IFNT under all four experimental treatments (Supplementary Table 1). Somewhat similar changes on genes playing a role in protein degradation and the NF- $\kappa B$ cascade have been noted when comparing endometrium of pregnant and nonpregnant cattle (Bauersachs et al. 2006).

\section{IFNT regulates the expression of angiogenesis factors}

The conceptus as it begins to form a close association with the uterine wall recruits a localized blood supply in the underlying maternal endometrium, which is accompanied by local edema in the regions where the trophoblast makes contact (Spencer et al. 2004). The formation of new blood vessels involves the coordinated actions of proteolytic enzymes, protease inhibitors, extracellular matrix components, and cell adhesion molecules. IFNA and IFNB are generally considered to be angiostatic, in part by down-regulating the production of FGF2 (Fidler 2000). On the other hand, IFNA has also been reported to increase expression of several angiogenic factors (de Veer et al. 2001). The response to IFNT in LE cells was also mixed (Table 4). Some genes were down-regulated, including FGF2, angiopoietin-1
(ANGPT1), VE-cadherin (CDH5), and HIF1A and EPAS1 (hypoxia-inducible factor- $2 \alpha$ ), which direct responses to low $\mathrm{O}_{2}$ conditions, while other genes implicated in blood vessel formation were up-regulated, e.g. angiopoietin-2 and -4 (ANG2 and ANG4), and vascular endothelial growth factors $\mathrm{B}$ and $\mathrm{C}$ (VEGFB and $V E G F C$. These ostensibly conflicting data are not easy to interpret and suggest complex effects of IFNT on angiogenesis in the endometrium. One possibility is that IFNT activates certain angiogenic pathways, such as the one that involves VEGF-VEGFR2 system, while at the same time it down-regulates pathways normally initiated by hypoxia. Such a complementary system for promoting angiogenesis has recently been reported in tumors (Casanovas et al. 2005). In the pregnant uterus, we propose that LE and possibly the upper, contiguous glandular epithelial cells, which are responsible for transducing signals received from the trophoblast to the underlying tissue, are stimulated to produce increased amounts of angiogenic factors such as VEGFs and therefore may direct the growth of new vessels from the existing capillary network bed.

In addition to its effects on genes associated with angiogenesis, IFNT up-regulated seven genes linked to blood coagulation (CD93, F2RL2, PLAU, TAUI, ANXA5, PLSCR1). The implications of such a link are unclear.

Table 4 Regulated genes related to angiogenesis.

\begin{tabular}{|c|c|c|c|c|c|c|}
\hline Unigene cluster ID & Gene name & Gene symbol & $\begin{array}{c}\mathbf{8 ~ h} \\
(10 \mathrm{ng} / \mathrm{ml})\end{array}$ & $\begin{array}{c}\mathbf{8} \mathbf{h} \\
(10 \mu \mathrm{g} / \mathrm{ml})\end{array}$ & $\begin{array}{c}\mathbf{2 4} \mathbf{h} \\
(10 \mathrm{ng} / \mathrm{ml})\end{array}$ & $\begin{array}{c}\mathbf{2 4 ~ h} \\
(10 \mu \mathrm{g} / \mathrm{ml})\end{array}$ \\
\hline Bt.13127 & Angiopoietin-1 (ANG-1) & ANGPT1 & 0.97 & 1.02 & 0.82 & 0.89 \\
\hline Bt.137 & Angiopoietin-2 (ANG-2) & ANG2 & 1.48 & 1.29 & 1.43 & 1.01 \\
\hline Bt.43747 & Angiopoietin-4 precursor (ANG-4) & ANG4 & 1.48 & 1.46 & 1.48 & 1.33 \\
\hline Bt.4725 & B-cell translocation gene 1 , antiproliferative & BTG1 & 1.07 & 0.74 & 1.01 & 0.65 \\
\hline Bt.23246 & $\begin{array}{l}\text { Cadherin 5, type 2, VE-cadherin (vascular } \\
\text { epithelium) }\end{array}$ & $\mathrm{CDH} 5$ & 0.57 & 1.37 & 0.56 & 1.4 \\
\hline Bt.6670 & Cardiovascular basic helix-loop-helix factor 2 & CHF2 & 1.92 & 1.54 & 2.24 & 1.43 \\
\hline Bt.5240 & Connective tissue growth factor & CTGF & 1.88 & 1.59 & 1.56 & 1.57 \\
\hline Bt.4353 & Endothelial PAS domain protein 1 & EPAS1 & 0.78 & 0.72 & 0.83 & 0.72 \\
\hline Bt.13998 & FGF intracellular-binding protein isoform b & FIBP & 0.82 & 0.8 & 0.7 & 0.81 \\
\hline Bt.12991 & Fibroblast growth factor 10 & FGF-10 & 0.62 & 0.72 & 0.79 & 0.56 \\
\hline Bt.4834 & Fibroblast growth factor 2 (basic) & FGF2 & 0.81 & 1.09 & 0.64 & 0.4 \\
\hline Bt.21540 & Fibroblast growth factor receptor 2 & FGFR2 & 0.92 & 0.65 & 0.5 & 0.67 \\
\hline Bt.5038 & $\begin{array}{l}\text { Fibroblast growth factor, acidic (endothelial } \\
\text { growth factor) }\end{array}$ & $R A B 24$ & 1.62 & 1.3 & 1.33 & 1.23 \\
\hline Bt.279 & $\begin{array}{l}\text { Fibroblast growth factor-binding protein } \\
\text { (FGF-BP) }\end{array}$ & LOC281812 & 1.03 & 1.1 & 0.6 & 0.77 \\
\hline Bt.4184 & $\begin{array}{l}\text { Hypoxia-inducible factor } 1, \alpha \text { subunit (basic } \\
\text { helix-loop-helix transcription factor) }\end{array}$ & HIF1A & 0.8 & 0.77 & 0.79 & 0.83 \\
\hline Bt.18203 & $\begin{array}{l}\text { Junctional adhesion molecule } 2 \text { precursor } \\
\text { (Vascular endothelial junction-associated } \\
\text { molecule) (VE-JAM) (Canis familiaris) }\end{array}$ & JAM2 & 0.48 & 0.82 & 0.63 & 0.85 \\
\hline Bt.45242 & Neuropilin 2 isoform 2 precursor & NRP2 & 0.77 & 0.91 & 0.78 & 0.89 \\
\hline Bt.9423 & Platelet-activating factor receptor & PAFR & 2.2 & 1.56 & 1.69 & 1.53 \\
\hline Bt.42912 & $\begin{array}{l}\text { Vascular cell adhesion molecule } 1 \text { isoform a } \\
\text { precursor }\end{array}$ & CD106 & 1.54 & 1.83 & 0.69 & 0.96 \\
\hline Bt.5402 & Vascular endothelial growth factor B & VEGFB & 1.67 & 1.93 & 1.68 & 1.9 \\
\hline Bt.3913 & Vascular endothelial growth factor C & VEGFC & 1.44 & 1.16 & 1.21 & 1.21 \\
\hline
\end{tabular}


Table 5 Regulated genes in the insulin-like growth factor system.

\begin{tabular}{|c|c|c|c|c|c|c|}
\hline Unigene cluster ID & Gene name & Gene symbol & $\mathbf{8} \mathbf{h}(10$ ng/ml) & $\mathbf{8} \mathbf{h}(10 \mu \mathrm{g} / \mathrm{ml})$ & $24 \mathbf{h}(10 \mathrm{ng} / \mathrm{ml})$ & $24 \mathbf{h}(10 \mu \mathrm{g} / \mathrm{ml})$ \\
\hline Bt.32572 & $\begin{array}{l}\text { Insulin-like growth } \\
\text { factor-binding } \\
\text { protein-like } 1\end{array}$ & IGFBPL 1 & 1.43 & 0.93 & 1.22 & 0.89 \\
\hline Bt.5237 & $\begin{array}{l}\text { Insulin-like growth } \\
\text { factor-binding } \\
\text { protein } 4 \text { (IGFBP-4) }\end{array}$ & IGFBP4 & 2.31 & 1.79 & 1.12 & 1.35 \\
\hline Bt.422 & $\begin{array}{l}\text { Insulin-like growth } \\
\text { factor-binding } \\
\text { protein } 3 \text { (IGFBP-3) }\end{array}$ & IGFBP3 & 9.84 & 7.67 & 6.04 & 6.83 \\
\hline Bt.23176 & $\begin{array}{l}\text { Insulin-like growth } \\
\text { factor } 2 \text { (IGF2) }\end{array}$ & IGF2 & 0.88 & 0.69 & 0.81 & 0.79 \\
\hline
\end{tabular}

\section{IFNT effects on the IGF system}

IGF2 is believed to play a major role in controlling nutrient balance between the mother and the conceptus (Reik et al. 2003). Its gene is paternally imprinted, i.e. expressed in a mono-allelic manner from the paternal chromosome. Interestingly, IGF2 was down-regulated in LE cells in response to IFNT (Table 5), a result consistent with that reported by us for in vivo effects (Chen et al. 2006). By contrast, IGFBP2, IGFBP3, and IGFBP4 became up-regulated in the LE cells. One possibility is that IFNT from the conceptus functions to repress or deregulate the local maternal IGF2 activity, possibly to gain control of maternal nutrient supply and angiogenesis.

\section{IFNT regulates expression of MMPs, TIMPs, and extracellular matrix components}

Proteins of the matrix metalloproteinase (MMP) family are involved in the degradation of extracellular matrix during many normal as well as pathological processes (Fata et al. 2000) and are also able to promote cell growth indirectly through interactions with cytokines and growth factors (Curry \& Osteen 2003). Tissue inhibitors of metalloproteinases (TIMPs) counteract and therefore modulate the activities of the MMPs and may also act as autocrine/paracrine factors in cellular proliferation and differentiation. IFNT down-regulated genes for several MMPs, up-regulated TIMP1, TIMP2, TIMP3, and TIMP4, and increased transcript concentrations for a number of genes encoding extracellular matrix components (Table 6). Others have demonstrated that IFNT inhibits production of MMPs in primary cultures of bovine endometrial cells (Salamonsen et al. 1994, Hashizume et al. 2003). In addition, these observations suggest that IFNT promotes extracellular matrix accretion rather than breakdown in the ovine uterus during the preimplantation period. By contrast, matrix degradation appears to play a role in the decidualization process during implantation in mouse (Das et al. 1997). Decidualization does not occur in species, such as the sheep, with a minimally invasive trophoblast. Conceivably, the action of IFNT is to prevent decidualization rather than to induce it.

\section{Other genes implicated in the luteoprotective action of IFNT}

As noted in our earlier in vivo work (Chen et al. 2006), IFNT can rapidly down-regulate OTR, which is consistent with the work of others over the last decade (Mirando et al. 1993, Lamming et al. 1995, Spencer et al. 1995a, 1995b). On the other hand, we failed to obtain a

Table 6 Genes related to extracellular matrix.

\begin{tabular}{|c|c|c|c|c|c|c|}
\hline Unigene cluster ID & Gene name & Gene symbol & $\begin{array}{c}\mathbf{8} \mathbf{h} \\
(10 \mathrm{ng} / \mathrm{ml})\end{array}$ & $\begin{array}{c}\mathbf{8} \mathbf{h} \\
(10 \mu \mathrm{g} / \mathrm{ml})\end{array}$ & $\begin{array}{c}\mathbf{2 4} \mathbf{h} \\
(10 \mathrm{ng} / \mathrm{ml})\end{array}$ & $\begin{array}{c}24 \mathbf{h} \\
(10 \mu \mathrm{g} / \mathrm{ml})\end{array}$ \\
\hline Bt.23318 & $\alpha 1$ type III collagen & COL3A1 & 1.91 & 1.4 & 1.25 & 1.23 \\
\hline Bt.41478 & $\alpha 1$ type VII collagen precursor & COL7A1 & 1.71 & 1.54 & 1.65 & 1.93 \\
\hline Bt.5273 & Integrin, $\alpha \mathrm{V}$ & ITGAV & 1.82 & 1.65 & 1.97 & 1.72 \\
\hline Bt.23172 & Integrin, $\beta 5$ & RPS23 & 1.8 & 1.98 & 1.8 & 1.91 \\
\hline Bt.17999 & Intercellular adhesion molecule-2 & ICAM2 & 1.47 & 1.61 & 1.33 & 1.34 \\
\hline Bt.39 & Matrix metalloproteinase 13 (collagenase 3) & MMP13 & 0.29 & 0.72 & 0.64 & 0.55 \\
\hline Bt.26938 & Matrix metalloproteinase 17 & MMP17 & 0.5 & 0.44 & 0.83 & 0.43 \\
\hline Bt.7179 & Matrix metalloproteinase 23B & $M M P 23 B$ & 0.71 & 0.81 & 0.41 & 0.88 \\
\hline Bt.43352 & $\begin{array}{l}\text { Matrix metalloproteinase } 28 \text { preproprotein } \\
\text { isoform } 1\end{array}$ & MMP28 & 0.79 & 0.63 & 0.66 & 0.6 \\
\hline Bt.4714 & Matrix metalloproteinase 9 & MMP9 & 0.58 & 0.83 & 0.86 & 0.91 \\
\hline Bt. 632 & Tissue inhibitor of metalloproteinase 1 (TIMP-1) & TIMP1 & 1.21 & 1.49 & 1.34 & 1.76 \\
\hline Bt.5136 & Tissue inhibitor of metalloproteinase 3 (TIMP-3) & TIMP3 & 1.56 & 1.19 & 1.77 & 1.7 \\
\hline Bt.42237 & Tissue inhibitor of metalloproteinase 4 (TIMP-4) & TIMP4 & 1.76 & 1.96 & 1.76 & 2.13 \\
\hline Bt.435 & Tissue inhibitor of metalloproteinase 2 (TIMP-2) & TIMP2 & 1.32 & 2.05 & 1.61 & 1.21 \\
\hline
\end{tabular}


sufficiently strong hybridization signal for the mRNA of either ESR1 or ESR2 to determine whether these genes were significantly regulated in our system by IFNT. One well-accepted model for the luteoprotective action of IFNT is that the cytokine causes reduction of OTR number on the uterine epithelium indirectly as an outcome of preventing the normal up-regulation of ESR1 (Spencer et al. 1995a, 1996), whereas in the nonpregnant cycle the rise in OTR allows the hormone, oxytocin to mediate PGF release (Robinson et al. 1999). Clearly, our results are consistent with one part of this model, namely the down-regulation of OTR in response to IFNT, but could not address the second.

\section{Conclusions}

The present study provides a comprehensive, descriptive profiling of gene expression in ovine LE cells in responsive to IFNT. Out of more than 15000 genes examined, we identified over 1200 genes that were regulated $(P<0.01)$. Of these, we concentrated on the genes whose transcripts changed most significantly $(P<0.001)$. Many of the genes identified in the present study as IFN responsive have been noted earlier by others in human cells in response to IFNA and IFNB (Der et al. 1998, Kim et al. 2003a, Yan et al. 2004). However, our list is more comprehensive and has also expanded our understanding of the likely biological activities of IFNT on a physiologically relevant cell type. Our results suggest that IFNT, like other Type I IFN, up-regulates many genes that undoubtedly play a role in the antiviral activities of this class of cytokine. However, it is also clear that IFNT action on the uterus likely involves effects on prostaglandin metabolism, apoptosis, extracellular matrix accretion, angiogenesis and blood coagulation, inflammation, and growth factor production and activity. The recognition that such processes are likely to be modulated as the conceptus begins to attach to the uterine wall provides new insights into how IFNT might act during early pregnancy and the likely complexity of its role in maternal recognition of pregnancy in ruminants.

\section{Acknowledgements}

We thank Dr Tom Spencer, Texas A \& M University, for supplying the LE cells and Norma McCormack for editing the manuscript and preparing the Figures and Tables. The authors declare that there is no conflict of interest that would prejudice the impartiality of this scientific work. Research was supported by a grant from NIH Grant HD 21896 to RMR.

\section{References}

Alexenko AP, Leaman DW, Li J \& Roberts RM 1997 The antiproliferative and antiviral activities of IFN- $\tau$ variants in human cells. Journal of Interferon and Cytokine Research 17 769-779.
Alexenko AP, Ealy AD \& Roberts RM 1999 The cross-species antiviral activities of different IFN- $\tau$ subtypes on bovine, murine, and human cells: contradictory evidence for therapeutic potential. Journal of Interferon and Cytokine Research 19 1335-1341.

Asselin E \& Fortier MA 2000 Detection and regulation of the messenger for a putative bovine endometrial 9-keto-prostaglandin $\mathrm{E}(2)$ reductase: effect of oxytocin and interferon- $\tau$. Biology of Reproduction 62 125-131.

Asselin E, Drolet P \& Fortier MA 1997a Cellular mechanisms involved during oxytocin-induced prostaglandin $\mathrm{F} 2 \alpha$ production in endometrial epithelial cells in vitro: role of cyclooxygenase-2. Endocrinology 138 4798-4805.

Asselin E, Lacroix D \& Fortier MA 1997b IFN- $\tau$ increases PGE2 production and $C O X-2$ gene expression in the bovine endometrium in vitro. Molecular and Cellular Endocrinology 132 117-126.

Asselin E, Bazer FW \& Fortier MA 1997c Recombinant ovine and bovine interferons $\tau$ regulate prostaglandin production and oxytocin response in cultured bovine endometrial cells. Biology of Reproduction $\mathbf{5 6}$ 402-408.

Austin KJ, Ward SK, Teixeira MG, Dean VC, Moore DW \& Hansen TR 1996 Ubiquitin cross-reactive protein is released by the bovine uterus in response to interferon during early pregnancy. Biology of Reproduction 54 600-606.

Bauersachs S, Ulbrich SE, Gross K, Schmidt SE, Meyer $\mathbf{H H}$, Wenigerkind $H$, Vermehren $M$, Sinowatz $F$, Blum $H$ \& Wolf $E$ 2006 Embryo-induced transcriptome changes in bovine endometrium reveal species-specific and common molecular markers of uterine receptivity. Reproduction 132 319-331.

Beckers RA, Chambers JM \& Wilks AR 1988 The New S Language, New York: Chapman \& Hall.

Berger J, Hautaniemi S, Jarvinen A-K, Edgren H, Mitra S \& Astola J 2004 Optimized LOWESS normalization parameter selection for DNA microarray data. BMC Bioinformatics 5194.

Binelli M, Guzeloglu A, Badinga L, Arnold DR, Sirois J, Hansen TR \& Thatcher WW 2000 Interferon- $\tau$ modulates phorbol ester-induced production of prostaglandin and expression of cyclooxygenase-2 and phospholipase-A(2) from bovine endometrial cells. Biology of Reproduction 63 417-424.

Brunner A, Yakovlev I \& Strauss S 2004 Validating internal controls for quantitative plant gene expression studies. BMC Plant Biology 414.

Casanovas O, Hicklin DJ, Bergers G \& Hanahan D 2005 Drug resistance by evasion of antiangiogenic targeting of VEGF signaling in late-stage pancreatic islet tumors. Cancer Cell 8 299-309.

Chawla-Sarkar M, Lindner DJ, Liu YF, Williams BR, Sen GC, Silverman RH \& Borden EC 2003 Apoptosis and interferons: role of interferon-stimulated genes as mediators of apoptosis. Apoptosis 8 237-249.

Chen Y, Green JA, Antoniou E, Ealy AD, Mathialagan N, Walker AM, Avalle MP, Rosenfeld CS, Hearne LB \& Roberts RM 2006 Effect of interferon- $\tau$ administration on endometrium of nonpregnant ewes: a comparison with pregnant ewes. Endocrinology 147 2127-2137.

Choi Y, Johnson GA, Burghardt RC, Berghman LR, Joyce MM, Taylor KM, Stewart MD, Bazer FW \& Spencer TE 2001 Interferon regulatory factor-two restricts expression of interferon-stimulated genes to the endometrial stroma and glandular epithelium of the ovine uterus. Biology of Reproduction 65 1038-1049.

Cui X \& Churchill GA 2003 Statistical tests for differential expression in cDNA microarray experiments. Genome Biology 4210.

Curry TE Jr \& Osteen KG 2003 The matrix metalloproteinase system: changes, regulation, and impact throughout the ovarian and uterine reproductive cycle. Endocrine Reviews 24 428-465.

Das SK, Yano S, Wang J, Edwards DR, Nagase H \& Dey SK 1997 Expression of matrix metalloproteinases and tissue inhibitors of metalloproteinases in the mouse uterus during the peri-implantation period. Developmental Genetics 21 44-54.

Dennis G Jr, Sherman BT, Hosack DA, Yang J, Gao W, Lane HC \& Lempicki RA 2003 DAVID: database for annotation, visualization, and integrated discovery. Genome Biology 4 P3. 
Der SD, Zhou A, Williams BR \& Silverman RH 1998 Identification of genes differentially regulated by interferon $\alpha, \beta$, or $\gamma$ using oligonucleotide arrays. PNAS 95 15623-15628.

Ealy AD, Alexenko AP, Keisler DH \& Roberts RM 1998a Loss of the signature six carboxyl amino acid tail from ovine interferon- $\tau$ does not affect biological activity. Biology of Reproduction $\mathbf{5 8}$ 1463-1468.

Ealy AD, Green JA, Alexenko AP, Keisler DH \& Roberts RM $1998 b$ Different ovine interferon- $\tau$ genes are not expressed identically and their protein products display different activities. Biology of Reproduction 58 566-573.

Eisen MB, Spellman PT, Brown PO \& Botstein D 1998 Cluster analysis and display of genome-wide expression patterns. PNAS 95 14863-14868.

Emond V, MacLaren LA, Kimmins S, Arosh JA, Fortier MA \& Lambert RD 2004 Expression of cyclooxygenase-2 and granulocyte-macrophage colony-stimulating factor in the endometrial epithelium of the cow is up-regulated during early pregnancy and in response to intrauterine infusions of interferon- $\tau$. Biology of Reproduction 70 54-64.

Farin CE, Imakawa K, Hansen TR, McDonnell JJ, Murphy CN, Farin PW \& Roberts RM 1990 Expression of trophoblastic interferon genes in sheep and cattle. Biology of Reproduction 43 210-218.

Fata JE, Ho AT, Leco KJ, Moorehead RA \& Khokha R 2000 Cellular turnover and extracellular matrix remodeling in female reproductive tissues: functions of metalloproteinases and their inhibitors. Cellular and Molecular Life Sciences 57 77-95.

Fidler IJ 2000 Angiogenesis and cancer metastasis. Cancer Journal 6 S134-S141.

Gray CA, Abbey CA, Beremand PD, Choi Y, Farmer JL, Adelson DL, Thomas TL, Bazer FW \& Spencer TE 2006 Identification of endometrial genes regulated by early pregnancy, progesterone, and interferon $\tau$ in the ovine uterus. Biology of Reproduction $\mathbf{7 4}$ 383-394.

Hansen TR, Imakawa K, Polites HG, Marotti KR, Anthony RV \& Roberts RM 1988 Interferon RNA of embryonic origin is expressed transiently during early pregnancy in the ewe. Journal of Biological Chemistry 263 12801-12804.

Hashizume K, Takahashi T, Shimizu M, Todoroki J, Shimada A, Hirata M, Sato T \& Ito A 2003 Matrix-metalloproteinases-2 and -9 production in bovine endometrial cell culture. Journal of Reproduction and Development 49 45-53.

Hegde P, Qi R, Abernathy K, Gay C, Dharap S, Gaspard R, Hughes JE, Snesrud E, Lee N \& Quackenbush J 2000 A concise guide to cDNA microarray analysis. Biotechniques 29 548-562.

Helmer SD, Hansen PJ, Anthony RV, Thatcher WW, Bazer FW \& Roberts RM 1987 Identification of bovine trophoblast protein-1, a secretory protein immunologically related to ovine trophoblast protein-1. Journal of Reproduction and Fertility 79 83-91.

Hicks BA, Etter SJ, Carnahan KG, Joyce MM, Assiri AA, Carling SJ, Kodali K, Johnson GA, Hansen TR, Mirando MA et al. 2003 Expression of the uterine $\mathrm{Mx}$ protein in cyclic and pregnant cows, gilts, and mares. Journal of Animal Science 81 1552-1561.

Ishiwata H, Katsuma S, Kizaki K, Patel OV, Nakano H, Takahashi T, Imai K, Hirasawa A, Shiojima S, Ikawa H et al. 2003 Characterization of gene expression profiles in early bovine pregnancy using a custom cDNA microarray. Molecular Reproduction and Development 65 9-18.

Johnson G, Austin K, Collins A, Murdoch W \& Hansen T 1999a Endometrial ISG17 mRNA and a related mRNA are induced by interferon- $\tau$ and localized to glandular epithelial and stromal cells from pregnant cows. Endocrine 10 243-252.

Johnson GA, Austin KJ, Collins AM, Murdoch WJ \& Hansen TR $1999 \mathrm{~b}$ Endometrial ISG17 mRNA and a related mRNA are induced by interferon- $\tau$ and localized to glandular epithelial and stromal cells from pregnant cows. Endocrine 10 243-252.

Johnson GA, Burghardt RC, Newton GR, Bazer FW \& Spencer TE 1999 C Development and characterization of immortalized ovine endometrial cell lines. Biology of Reproduction 61 1324-1330.
Johnson GA, Spencer TE, Hansen TR, Austin KJ, Burghardt RC \& Bazer FW 1999d Expression of the interferon $\tau$ inducible ubiquitin cross-reactive protein in the ovine uterus. Biology of Reproduction $61312-318$.

Johnson GA, Spencer TE, Burghardt RC, Joyce MM \& Bazer FW 2000 Interferon- $\tau$ and progesterone regulate ubiquitin cross-reactive protein expression in the ovine uterus. Biology of Reproduction 62 622-627.

Johnson G, Stewart M, Gray C, Choi Y, Burghardt R, Yu-Lee L, Bazer F \& Spencer T 2001a Effects of the estrous cycle, pregnancy, and interferon $\tau$ on $2^{\prime}, 5^{\prime}$-oligoadenylate synthetase expression in the ovine uterus. Biology of Reproduction 64 1392-1399.

Johnson GA, Stewart MD, Gray CA, Choi Y, Burghardt RC, Yu-Lee LY, Bazer FW \& Spencer TE 2001b Effects of the estrous cycle, pregnancy, and interferon $\tau$ on $2^{\prime}, 5^{\prime}$-oligoadenylate synthetase expression in the ovine uterus. Biology of Reproduction 64 1392-1399.

Johnson GA, Joyce MM, Yankey SJ, Hansen TR \& Ott TL 2002 The interferon stimulated genes (ISG) 17 and $M x$ have different temporal and spatial expression in the ovine uterus suggesting more complex regulation of the $M x$ gene. Journal of Endocrinology 174 R7-R11.

Kim S, Choi Y, Bazer FW \& Spencer TE 2003a Identification of genes in the ovine endometrium regulated by interferon $\tau$ independent of signal transducer and activator of transcription 1. Endocrinology 144 5203-5214.

Kim S, Choi Y, Spencer TE \& Bazer FW 2003b Effects of the estrous cycle, pregnancy and interferon $\tau$ on expression of cyclooxygenase two (COX-2) in ovine endometrium. Reproductive Biology and Endocrinology 158.

Klein C, Bauersachs S, Ulbrich SE, Einspanier R, Meyer HH, Schmidt SE, Reichenbach HD, Vermehren M, Sinowatz F, Blum H et al. 2006 Monozygotic twin model reveals novel embryo-induced transcriptome changes of bovine endometrium in the preattachment period. Biology of Reproduction 74 253-264.

Knickerbocker JJ \& Niswender GD 1989 Characterization of endometrial receptors for ovine trophoblast protein- 1 during the estrous cycle and early pregnancy in sheep. Biology of Reproduction 40 361-369.

Lamming GE, Wathes DC, Flint AP, Payne JH, Stevenson KR \& Vallet JL 1995 Local action of trophoblast interferons in suppression of the development of oxytocin and oestradiol receptors in ovine endometrium. Journal of Reproduction and Fertility 105 165-175.

Leaman DW, Chawla-Sarkar M, Jacobs B, Vyas K, Sun Y, Ozdemir A, Yi T, Williams BR \& Borden EC 2003 Novel growth and death related interferon-stimulated genes (ISGs) in melanoma: greater potency of IFN- $\beta$ compared with IFN- $\alpha 2$. Journal of Interferon and Cytokine Research 23 745-756.

Li XL \& Hassel BA 2001 Involvement of proteasomes in gene induction by interferon and double-stranded RNA. Cytokine 14 247-252.

Li J \& Roberts RM 1994 Interferon- $\tau$ and interferon- $\alpha$ interact with the same receptors in bovine endometrium. Use of a readily iodinatable form of recombinant interferon- $\tau$ for binding studies. Journal of Biological Chemistry 269 13544-13550.

Liu M, Li XL \& Hassel BA 2003 Proteasomes modulate conjugation to the ubiquitin-like protein, ISG15. Journal of Biological Chemistry 278 1594-1602.

Magness RR, Huie JM, Hoyer GL, Huecksteadt TP, Reynolds LP, Seperich GJ, Whysong G \& Weems CW 1981 Effect of chronic ipsilateral or contralateral intrauterine infusion of prostaglandin E2 (PGE2) on luteal function of unilaterally ovariectomized ewes. Prostaglandins and Medicine 6 389-401.

McCracken JA, Custer EE \& Lamsa JC 1999 Luteolysis: a neuroendocrine-mediated event. Physiological Reviews 79 263-323.

Mirando MA, Harney JP, Zhou Y, Ogle TF, Ott TL, Moffatt RJ \& Bazer FW 1993 Changes in progesterone and oestrogen receptor mRNA and protein and oxytocin receptors in endometrium of ewes after intrauterine injection of ovine trophoblast interferon. Journal of Molecular Endocrinology 10 185-192. 
Opferman JT \& Korsmeyer SJ 2003 Apoptosis in the development and maintenance of the immune system. Nature Immunology $\mathbf{4}$ $410-415$.

Ott TL, Yin J, Wiley AA, Kim HT, Gerami-Naini B, Spencer TE, Bartol FF, Burghardt RC \& Bazer FW 1998 Effects of the estrous cycle and early pregnancy on uterine expression of Mx protein in sheep (Ovis aries). Biology of Reproduction 59 784-794.

Parent J, Villeneuve C, Alexenko AP, Ealy AD \& Fortier MA 2003 Influence of different isoforms of recombinant trophoblastic interferons on prostaglandin production in cultured bovine endometrial cells. Biology of Reproduction 68 1035-1043.

Payne JH \& Lamming GE 1994 The direct influence of the embryo on uterine PGF2 $\alpha$ and PGE2 production in sheep. Journal of Reproduction and Fertility 101 737-741.

Pestka S, Krause CD \& Walter MR 2004 Interferons, interferon-like cytokines, and their receptors. Immunological Reviews 202 8-32.

Pru JK, Rueda BR, Austin KJ, Thatcher WW, Guzeloglu A \& Hansen TR 2001 Interferon- $\tau$ suppresses prostaglandin F2 $\alpha$ secretion independently of the mitogen-activated protein kinase and nuclear factor $\kappa \mathrm{B}$ pathways. Biology of Reproduction 64 965-973.

Reik W, Constancia M, Fowden A, Anderson N, Dean W, FergusonSmith A, Tycko B \& Sibley C 2003 Regulation of supply and demand for maternal nutrients in mammals by imprinted genes. Journal of Physiology 547 35-44.

Roberts RM, Cross JC \& Leaman DW 1992 Interferons as hormones of pregnancy. Endocrine Reviews 13 432-452.

Roberts RM, Liu L \& Alexenko A 1997 New and atypical families of type I interferons in mammals: comparative functions, structures, and evolutionary relationships. Progress in Nucleic Acid Research and Molecular Biology 56 287-325.

Robinson RS, Mann GE, Lamming GE \& Wathes DC 1999 The effect of pregnancy on the expression of uterine oxytocin, oestrogen and progesterone receptors during early pregnancy in the cow. Journal of Endocrinology 160 21-33.

Rosenfeld CS, Han CS, Alexenko AP, Spencer TE \& Roberts RM 2002 Expression of interferon receptor subunits, IFNAR1 and IFNAR2, in the ovine uterus. Biology of Reproduction 67 847-853.

Salamonsen LA, Hampton AL, Suzuki R \& Nagase H 1994 Modulation of production of matrix metalloproteinases from ovine endometrial cells by ovine trophoblast interferon. Journal of Reproduction and Fertility 102 155-162.

Silvia WJ, Ottobre JS \& Inskeep EK 1984 Concentrations of prostaglandins E2, F2 $\alpha$ and 6-keto-prostaglandin F1 $\alpha$ in the utero-ovarian venous plasma of nonpregnant and early pregnant ewes. Biology of Reproduction 30 936-944.

Simmons DL, Botting RM \& Hla T 2004 Cyclooxygenase isozymes: the biology of prostaglandin synthesis and inhibition. Pharmacological Reviews 56 387-437.

Smith TP, Grosse WM, Freking BA, Roberts AJ, Stone RT, Casas E, Wray JE, White J, Cho J, Fahrenkrug SC et al. 2001 Sequence evaluation of four pooled-tissue normalized bovine cDNA libraries and construction of a gene index for cattle. Genome Research $\mathbf{1 1}$ 626-630.

Spencer TE \& Bazer FW 1996 Ovine interferon $\tau$ suppresses transcription of the estrogen receptor and oxytocin receptor genes in the ovine endometrium. Endocrinology 137 1144-1147.

Spencer TE, Becker WC, George P, Mirando MA, Ogle TF \& Bazer FW $1995 a$ Ovine interferon- $\tau$ regulates expression of endometrial receptors for estrogen and oxytocin but not progesterone. Biology of Reproduction $\mathbf{5 3}$ 732-745.

Spencer TE, Becker WC, George P, Mirando MA, Ogle TF \& Bazer FW $1995 b$ Ovine interferon- $\tau$ inhibits estrogen receptor up-regulation and estrogen-induced luteolysis in cyclic ewes. Endocrinology 136 4932-4944.

Spencer TE, Mirando MA, Mayes JS, Watson GH, Ott TL \& Bazer FW 1996 Effects of interferon- $\tau$ and progesterone on oestrogen- stimulated expression of receptors for oestrogen, progesterone and oxytocin in the endometrium of ovariectomized ewes. Reproduction, Fertility, and Development 8 843-853.

Spencer TE, Johnson GA, Bazer FW \& Burghardt RC 2004 Implantation mechanisms: insights from the sheep. Reproduction 128 657-668.

Stark GR, Kerr IM, Williams BR, Silverman RH, Schreiber RD \& Schreiber RD 1998 How cells respond to interferons. Annual Review of Biochemistry 67 227-264.

Stewart DM, Johnson GA, Vyhlidal CA, Burghardt RC, Safe SH, YuLee LY, Bazer FW \& Spencer TE 2001a Interferon- $\tau$ activates multiple signal transducer and activator of transcription proteins and has complex effects on interferon-responsive gene transcription in ovine endometrial epithelial cells. Endocrinology 142 98-107.

Stewart MD, Johnson GA, Bazer FW \& Spencer TE $2001 b$ Interferon- $\tau$ $(\mathrm{IFN} \tau)$ regulation of IFN-stimulated gene expression in cell lines lacking specific IFN-signaling components. Endocrinology 142 1786-1794.

Takasuga A, Hirotsune S, Itoh R, Jitohzono A, Suzuki H, Aso H \& Sugimoto Y 2001 Establishment of a high throughput EST sequencing system using poly(A) tail-removed CDNA libraries and determination of 36000 bovine ESTs. Nucleic Acids Research 29 E108.

Thibodeaux JK, Myers MW, Roussel JD \& Godke RA 1992 Intrauterine infusion of prostaglandin E2 and subsequent luteal function in cattle. Prostaglandins 44 531-541.

Uddin S, Lekmine F, Sharma N, Majchrzak B, Mayer I, Young PR, Bokoch GM, Fish EN \& Platanias LC 2000 The Rac1/p38 mitogenactivated protein kinase pathway is required for interferon $\alpha$-dependent transcriptional activation but not serine phosphorylation of stat proteins. Journal of Biological Chemistry 275 27634-27640.

de Veer MJ, Holko M, Frevel M, Walker E, Der S, Paranjape JM, Silverman RH \& Williams BR 2001 Functional classification of interferon-stimulated genes identified using microarrays. Journal of Leukocyte Biology 69 912-920.

Wang K, Yin XM, Chao DT, Milliman CL \& Korsmeyer SJ 1996 BID: a novel $\mathrm{BH} 3$ domain-only death agonist. Genes and Development 10 2859-2869.

Wang B, Xiao C \& Goff AK 2003 Progesterone-modulated induction of apoptosis by interferon- $\tau$ in cultured epithelial cells of bovine endometrium. Biology of Reproduction 68 673-679.

Wu H, Kerr MK, Cui X \& Churchill GA 2002 In MAANOVA: A Software Package for the Analysis of Spotted cDNA Microarray Experiments, Eds G Parmigiani, ES Garett, RA Irizarry \& SL Zeger. Berlin: Springer.

Xiao CW, Liu JM, Sirois J \& Goff AK 1998 Regulation of cyclooxygenase-2 and prostaglandin $\mathrm{F}$ synthase gene expression by steroid hormones and interferon- $\tau$ in bovine endometrial cells. Endocrinology 139 2293-2299.

Xiao CW, Murphy BD, Sirois J \& Goff AK 1999 Down-regulation of oxytocin-induced cyclooxygenase- 2 and prostaglandin $\mathrm{F}$ synthase expression by interferon- $\tau$ in bovine endometrial cells. Biology of Reproduction 60 656-663.

Yan W, Lee H, Yi EC, Reiss D, Shannon P, Kwieciszewski BK, Coito C, Li XJ, Keller A, Eng J et al. 2004 System-based proteomic analysis of the interferon response in human liver cells. Genome Biology 5 R54.

Yang E, Zha J, Jockel J, Boise LH, Thompson CB \& Korsmeyer SJ 1995 $\mathrm{Bad}$, a heterodimeric partner for $\mathrm{Bcl}-\mathrm{XL}$ and $\mathrm{BCl}-2$, displaces Bax and promotes cell death. Cell 80 285-291.

Received 21 December 2006

First decision 2 February 2007

Accepted 2 April 2007 